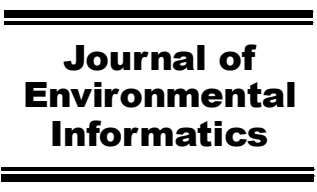

www.iseis.org/jei

\title{
Phosphorus Fractions and Its Summer's Release Flux From Sediment in the China's Three Gorges Reservoir
}

\author{
Y. C. Wang ${ }^{1,2}$, F. X. Niu ${ }^{3}$, S. B. Xiao ${ }^{3, *}$ D. F. Liu', W. Z. Chen ${ }^{3}$, L. Wang ${ }^{3}$, Z. J. Yang ${ }^{3}$, D. B. Ji ${ }^{3}$, G. Y. Li ${ }^{3}$, \\ H. C. $\mathrm{Guo}^{3}$, and $\mathrm{Y} \cdot \mathrm{Li}^{3}$ \\ ${ }^{1}$ Department of Water Environment, Institute of Water Resources and Hydropower Research, Beijing 100038, China \\ ${ }^{2}$ State Key Laboratory of Simulation and Regulation of Water Cycle in River Basin, Institution of Water Resources and Hydropower Research, \\ Beijing 100038, China \\ ${ }^{3}$ College of Hydraulic and Environment Engineering, Three Gorges University, Yichang 443002, China
}

Received 25 May 2012; revised 13 January 2013; accepted 28 July 2013; published online 21 May 2014

\begin{abstract}
The amounts and forms of phosphorus (P) in sediments, orthophosphate (Pi) concentrations as well as Pi release fluxes across the sediment-water interface were investigated from five sampling sites in the Three-Gorges Reservoir (TGR). The Total P (TP) contents of surface sediments $(0-2 \mathrm{~cm})$ ranged from 415.5 to $1047.9 \mathrm{mg} / \mathrm{kg}$, and the predominant fraction was $\mathrm{HCl}-\mathrm{P}(\mathrm{Ca}-\mathrm{bound} \mathrm{P})$. The main rank order of P-fractions was HCl-P > Res-P (Residual-P) > NaOH-P (Al-adsorbed P) > BD-P (Redox sensitive P) > $\mathrm{NH}_{4} \mathrm{Cl}-\mathrm{P}$ (Labile P), and ranged from 164.5 to $687.2 \mathrm{mg} / \mathrm{kg}, 96.0$ to $140.8 \mathrm{mg} / \mathrm{kg}, 75.8$ to $111.5 \mathrm{mg} / \mathrm{kg}, 34.0$ to $104.8 \mathrm{mg} / \mathrm{kg}$, and 5.9 to $15.9 \mathrm{mg} / \mathrm{kg}$, respectively. The $\mathrm{pH}$ values ranged from 6.4 to 8.2 across sediment-water interface and sediment $\mathrm{pH}$ values were lower than those of the corresponding overlying water. The average Pi concentrations of pore water were higher than those of the open water and overlying water. Based on calculations using the Fick's first law, sediment in Xiangxi River (XX03) functioned as a P sink, with Pi flux of $-0.003 \mathrm{mg} / \mathrm{m}^{2} / \mathrm{d}$, while sediments from Modaoxi03 (MDX03), Daning02 (DN02), Caotanghe (CTH) and Changjiang Badong (CJBD), had Pi fluxes of $0.013 \mathrm{mg} / \mathrm{m}^{2} / \mathrm{d}, 0.009 \mathrm{mg} / \mathrm{m}^{2} / \mathrm{d}, 0.004 \mathrm{mg} / \mathrm{m}^{2} / \mathrm{d}$ and $0.007 \mathrm{mg} / \mathrm{m}^{2} / \mathrm{d}$, respectively, and served as an internal P source in summer.
\end{abstract}

Keywords: phosphorus fractions, sequential extraction, sediment, release fluxes, orthophosphate, $\mathrm{pH}$, Three-Gorges Reservoir

\section{Introduction}

Phosphorus (P) has been identified as the "limiting nutrient" to phytoplankton development (Jin et al., 2006a; Khan and Ansari, 2005) and orthophosphate (Pi) is the only form of $\mathrm{P}$ that can be assimilated by bacteria, algae, and plants. Excessive concentration of $\mathrm{P}$ is the most common cause of eutrophication in freshwater lakes, reservoirs, streams, and head waters of estuarine systems (Correll, 1998). Therefore, controlling $\mathrm{P}$ has been well accepted as the best approach for reducing eutrophication (Dahl et al., 1993). To improve water quality, it will be necessary to further reduce the $\mathrm{P}$ sources including sediment release, especially when external pollution is reduced (Abrams and Jarrell, 1995; Sun et al., 2009; Xie et al., 2003). The factors affecting $\mathrm{P}$ release processes from sediments have been extensively studied over the past years (Boström, 1988; Jensen and Andersen, 1992). Most of the previous studies focused on the relevant environmental

\footnotetext{
${ }^{*}$ Corresponding author. Tel.: +86 7176399001 ; fax: +867176392318.

E-mail address: shangbinx@163.com (S. B. Xiao).
}

ISSN: 1726-2135 print/1684-8799 online

(C) 2013 ISEIS All rights reserved. doi: 10.3808/jei.201400260 factors e.g. temperature, $\mathrm{pH}$, redox potential and hydrological conditions (Andersen, 1974; Kim et al., 2003; Ramin and Bates, 1979). However, the release of $\mathrm{P}$ from surface sediments depends not only on the environmental factors, but also on the concentration of mobile $\mathrm{P}$ and transport processes, primarily diffusion (Rydin, 2000). Thus, it is of importance to probe $\mathrm{P}$ release, physical and chemical properties of sediments, especially the factors as well as processes affectting $\mathrm{P}$ release.

The Three-Gorges Project (TGP), regarded as the biggest water-control project in the world, has been operated at full capacity since the end of 2008 (Fu et al., 2010). The Three-Gorges Reservoir Area (TGRA), from Jiangjin District of Chongqing to Yichang City of Hubei, covers 20 countylevel administrative regions with an area of $58,000 \mathrm{~km}^{2}$ in total and the reservoir surface water area is over $1,080 \mathrm{~km}^{2}$ at a water level of $175 \mathrm{~m}$ with storage capacity of 39.3 billion $\mathrm{m}^{3}$ (Huang, 2001; Wu et al., 2003; Fu et al., 2010). The annual runoff flow at the Three Gorges Dam (TGD) is 451 billion $\mathrm{m}^{3}$ with the annual sediment discharge of $5.30 \times 10^{8} \mathrm{t}$. However, some environmental problems and challenges have to be faced for the TGP, especially the decrease of water quality of reservoir bays and backwater areas of its main tributaries $(\mathrm{Fu}$ 


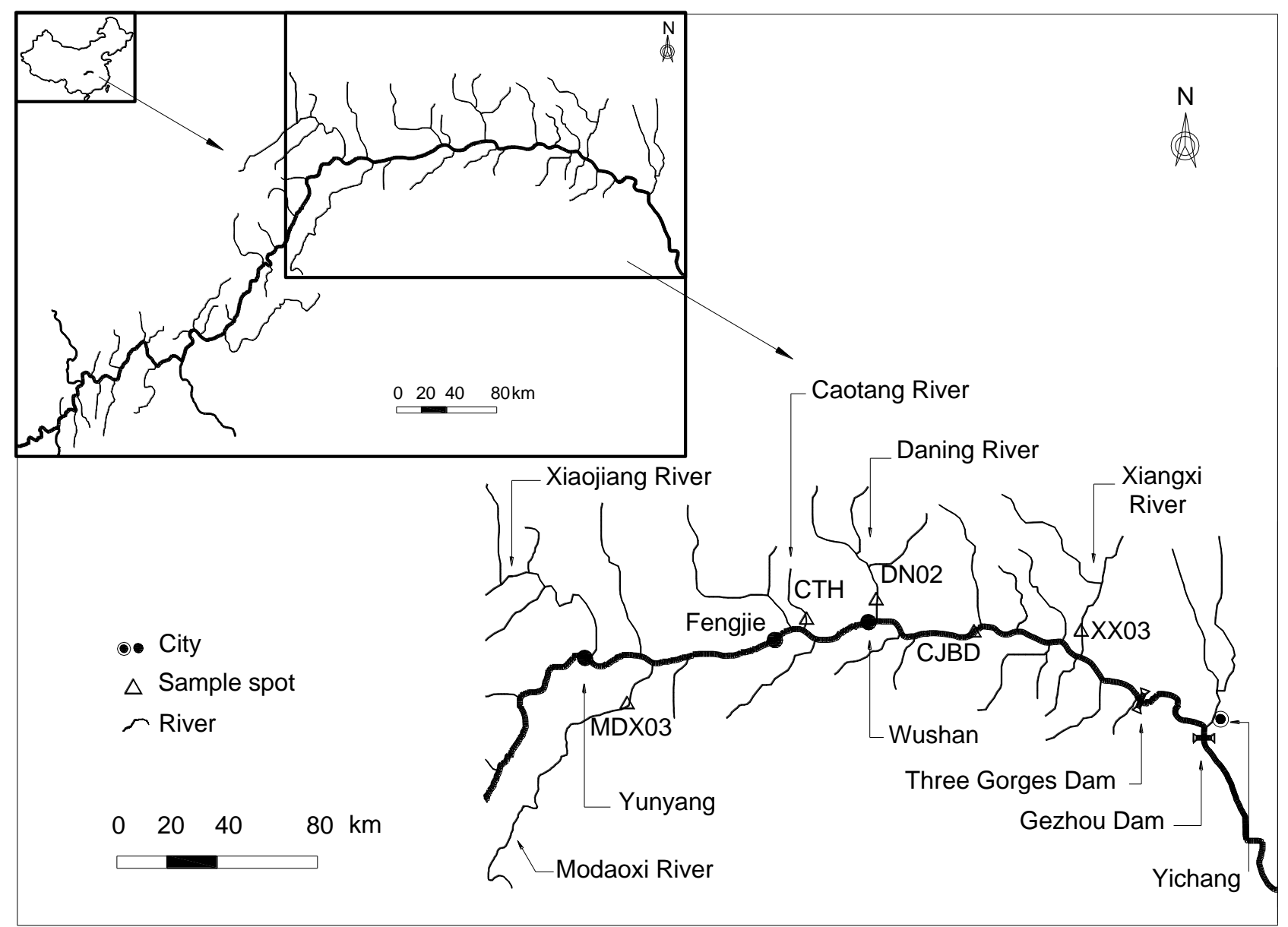

Figure 1. The geographic location of the sampling sites in the Three Gorges Reservoir.

Table 1. Geographic and Morphometric Features of the Related Rivers

\begin{tabular}{|c|c|c|c|c|c|c|c|c|}
\hline \multirow{3}{*}{ River } & \multirow{3}{*}{ Position } & \multirow[t]{2}{*}{$\begin{array}{l}\text { Drainage } \\
\text { area }\end{array}$} & \multirow[t]{2}{*}{$\begin{array}{l}\text { Sampling } \\
\text { site depth }\end{array}$} & \multirow{2}{*}{$\begin{array}{l}\text { Average } \\
\text { annual } \\
\text { runoff }\end{array}$} & \multirow{2}{*}{$\begin{array}{l}\text { Annual } \\
\text { average } \\
\text { flow } \\
\end{array}$} & \multicolumn{2}{|c|}{$\begin{array}{l}\text { Annual nutrient input } \\
\text { amount of nutrient }\end{array}$} & \multirow[t]{3}{*}{ References } \\
\hline & & & & & & $\mathrm{TN}$ & $\mathrm{TP}$ & \\
\hline & & $\mathrm{km}^{2}$ & $\mathrm{~m}$ & $10^{8} \mathrm{~m}^{3}$ & $\mathrm{~m}^{3} / \mathrm{s}$ & $10^{3} \mathrm{~kg}$ & $10^{3} \mathrm{~kg}$ & \\
\hline $\begin{array}{l}\text { Xiangxi } \\
\text { River }\end{array}$ & $\begin{array}{l}31^{\circ} 5^{\prime} 21^{\prime \prime} \mathrm{N} \\
110^{\circ} 45^{\prime} 5^{\prime \prime} \mathrm{E}\end{array}$ & 3,099 & 48 & 19.56 & 62.5 & $1,623.49$ & 331.85 & $\begin{array}{l}\text { Li et al., 2008; Zheng et } \\
\text { al., } 2008\end{array}$ \\
\hline $\begin{array}{l}\text { Daning } \\
\text { River }\end{array}$ & $\begin{array}{l}31^{\circ} 08^{\prime} 36^{\prime \prime} \mathrm{N} \\
109^{\circ} 53^{\prime} 58^{\prime \prime} \mathrm{E}\end{array}$ & 4,181 & 56 & 33.43 & 106 & $2,008.84$ & 34.06 & $\begin{array}{l}\text { Zhang et al., 2007; Hua } \\
\text { et al., } 2009\end{array}$ \\
\hline $\begin{array}{l}\text { Modaoxi } \\
\text { River }\end{array}$ & $\begin{array}{l}30^{\circ} 51^{\prime} 55^{\prime \prime} \mathrm{N} \\
108^{\circ} 52^{\prime} 40^{\prime \prime} \mathrm{E}\end{array}$ & 3,167 & 33 & 17.6 & 55.8 & - & - & \\
\hline $\begin{array}{l}\text { Caotang } \\
\text { River }\end{array}$ & $\begin{array}{l}31^{\circ} 02^{\prime} 55^{\prime \prime} \mathrm{N} \\
109^{\circ} 34^{\prime} 37^{\prime \prime} \mathrm{E}\end{array}$ & 210 & 54 & 2.369 & 7.51 & - & - & Chen et al., 2004 \\
\hline Badong & $\begin{array}{l}31^{\circ} 02^{\prime} 49^{\prime \prime} \mathrm{N} \\
110^{\circ} 23^{\prime} 10^{\prime \prime} \mathrm{E}\end{array}$ & - & 88 & - & - & - & - & \\
\hline
\end{tabular}

et al., 2010). Since 2004, algal blooms caused mainly by dinoflagellates have occurred in the 22 tributaries including the Xiangxi, Tongzhuang, and Daning Rivers each February (Fu et al., 2010). The occurence of algal blooms is directly linked to slow tributary flow caused by the impoundment (Deng and Gong, 2007; Li et al., 2007a; Yang et al., 2010), and changed water chemistry (Ye et al., 2006). The slow flow can weaken the water exchange in vertical direction, and protract the residence time of water which leads to the deposition of nutrient and particulates (Li et al., 2007a; Zheng et al., 2008). In some tributaries, the flow velocities were even below 0.05 m/s (Deng and Gong, 2007; Li et al., 2007a; Li et 
al., 2007b; Yang et al., 2010). Increased fertilizer use and decreased fertilizer use efficiency are implicated as another major causal factors for increased riverine nutrient transport (Liu et al., 2006). The application of chemical ferlizer from 1996 to 2007 in the TGRA increased by $23 \%$ (Fu et al., 2010). Other sources are from agricultural and industrial waste, sanitary waste discharge, the release of the sediments and so on. Therefore, rational regulation of the water and sediment to mitigate the negative ecological and environmental impacts is challenging on the Yangtze River.

The objective of this study was to analyze the orthophosphate $(\mathrm{Pi})$ concentrations in water body and to estimate the amounts and forms of total phosphorus (TP) and P fractionations of sediments in the whole profiles. Fick's First Law was used to evaluate summer's release fluxes of the studied sediments, and the factors affecting P release were also dis cussed.

\section{Materials and Methods}

\subsection{Study Area}

The sampling sites were located at the mainstream and tributaries of the TGRA (Figure 1). Xiangxi03 (XX03), Daning02 (DN02) and Modaoxi03 (MDX 03) were situated at the midstream of Modaoxi, Daning and Xiangxi River, Caotanghe $(\mathrm{CTH})$ was located at the estuary of Caotang River and Changjiang Badong (CJBD) was taken from the mainstream of the Yangtze River near the Badong County. Detailed locations and morphometric features of the five sampling sites were shown in Table 1.

\subsection{Sampling}

Undisturbed samples were collected from the five sampling sites along the Yangtze River during 31st, July to 4th, August 2011. Open water samples were separately obtained from the surface, middle and bottom water of each sampling profile $(0.5 \mathrm{~m}$ underneath water level, 0.6 and 0.8 times the depth of water depth, respectively) with card cover type water harvesting device, and stored in $200 \mathrm{~mL}$ polyvinyl chlo (PVC) bottles. The water temperature of the hypolimnion was measured using water thermometer. The corresponding overlying water (near the sediment-water interface) and sediment samples were collected using a gravity corer (Wang et al., 1998) with Plexiglas sampling tubes (diameter $6.5 \mathrm{~cm}$ and length $60 \mathrm{~cm}$ ). The subsampling of overlying water and sediments as well as the determination of $\mathrm{pH}$ values was carried out in situ. The $\mathrm{pH}$ values were measured using a glass electrode and overlying water samples collected by the gravity corer had a length of $18,12,8,10$, and $10 \mathrm{~cm}$ in XX03, DN02, MDX03, CTH and CJBD, respectively. Stratified overlying water was injected into PVC bottles at an interval of $2 \mathrm{~cm}$. The sediment cores obtained from the top $10 \mathrm{~cm}$ layer, were continuously sub-sampled into sections of $2 \mathrm{~cm}$ length, were fully packed in polyethylene centrifuge tubes and sealed to avoid sediment oxidation in the subsampling process. All samples were collected in triplicates, taken in air-sealed plastic bags and kept at $4{ }^{\circ} \mathrm{C}$ prior to analysis (within $12 \mathrm{~h}$ ).

\subsection{Analysis}

\subsubsection{Water Chemistry}

Open water samples, overlying water and pore water (extracted from sediment samples by centrifugation at $4000 \mathrm{rpm}$ for 30 minutes) samples from the five sampling sites were immediately filtered through $0.45 \mu \mathrm{m}$ Whatman $\mathrm{GF} / \mathrm{C}$ filters (Bakri and Chowdhury, 2006). The filtered water samples were analyzed immediately to determine the concentrations of orthophosphate $(\mathrm{Pi})$, with the molybdenum blue method (Wei et al., 2002). All samples were analyzed in triplicates and the data were reported as their average.

\subsubsection{Sediment Analysis and Phosphorus Fractions}

Part of sediments were used to calculate the water content and porosity, which were measured based on weight loss after drying of the sediments at $105^{\circ} \mathrm{C}$ (Egemose et al., 2009; Kaiserli et al., 2002). The other sediment samples after centrifuged were freeze-dried, homogenized, passed through a 200 mesh sieve and stored in the dryer. Sieved sediment sample $(0.50 \mathrm{~g})$, used for sediment TP determination, was put into 50 $\mathrm{ml}$ tube, and digested with $\mathrm{K}_{2} \mathrm{~S}_{2} \mathrm{O}_{8}$ and $\mathrm{H}_{2} \mathrm{SO}_{4}(30 \% \mathrm{v} / \mathrm{v})$ at $110{ }^{\circ} \mathrm{C}$ for $15 \mathrm{~min}$ (Gächter et al., 1992), thereafter deionized water was added into each tube to obtain a solid/water ratio at 1:100 (W/W). Then $\mathrm{P}$ was determined with the acidic molybdate ascorbic acid method (Murphy and Riley, 1962; Zhou et al., 2001). All samples were analyzed in triplicates and the data were reported as their average.

Phosphorus fractionations were determined using the sequential extraction scheme given by Christophoridis and Fytianos (2006) (Table 2). $0.30 \mathrm{~g}$ sediment sample was used and the extracts with a solid/water ratio of $1: 100(\mathrm{~W} / \mathrm{W})$ were centrifuged at $4,000 \mathrm{r} / \mathrm{min}$ for $30 \mathrm{~min}$. The supernatants were filtered through a $0.45 \mu \mathrm{m} \mathrm{GF} / \mathrm{C}$ filter membrane. The soluble reactive $\mathrm{P}$ (SRP) in each sample was determined according to the molybdenum blue method (Wei et al., 2002). This extraction procedure divided $\mathrm{P}$ fractions into loosely sorbed $\mathrm{P}$ $\left(\mathrm{NH}_{4} \mathrm{Cl}-\mathrm{P}\right)$, redox-sensitive $\mathrm{P}$ (BD-P), metal oxide bound $\mathrm{P}$ (NaOH-P), calcium bound $\mathrm{P}(\mathrm{HCl}-\mathrm{P})$ and residual $\mathrm{P}$ (Res-P). Res-P was calculated as TP minus total extracted P. Table 2 provided a summary of the fractions determined according to the selected scheme (Christophoridis and Fytianos, 2006). For each fraction, three replicates were performed and all the data were expressed as the average.

\subsection{Flux Estimation Methods}

Theoretical release flux rates were estimated from the gradients of Pi concentration present at the interface of water and sediment according to Fick's First Law (Berner, 1980):

$J=-\phi D_{s}(\partial C / \partial x)_{x=0}$,

where $J$ is the release flux $\left(\mathrm{mg} / \mathrm{m}^{2} / \mathrm{d}\right) ; \phi$ is the porosity in the upper part $(0 \sim 4 \mathrm{~cm})$ of the sediment; and $(\partial C / \partial x)_{x=0}$ is the concentration gradient of orthophosphate across the sediment- 
Table 2. Phosphorus Fractions in the Sediment and Their Descriptions (Christophoridis and Fytianos, 2006)

\begin{tabular}{|c|c|c|}
\hline Fraction & & Description \\
\hline $\mathrm{NH}_{4} \mathrm{Cl}-\mathrm{P}$ & Labile P & P loosely adsorbed to surface, immediately available \\
\hline BD-P & Redox sensitive $\mathrm{P}$ & $\begin{array}{l}\text { Redox-sensitive } \mathrm{P} \text {, bound to the surface of } \mathrm{Fe} \text { and } \mathrm{Mn} \text { oxides and hydroxides; released by reductive } \mathrm{Fe} \\
\text { dissolution }\end{array}$ \\
\hline $\mathrm{NaOH}-\mathrm{P}$ & $\begin{array}{l}\mathrm{P} \text { bound to metal oxide, } \\
\text { mainly of } \mathrm{Fe} \text { and } \mathrm{Al}\end{array}$ & $\begin{array}{l}\mathrm{P} \text { sorbed on the surface of } \mathrm{Al} \text { oxides and the interior of Fe oxides; released at high } \mathrm{pH} \text { due to ligand } \\
\text { exchange reactions in which hydroxide ions replace orthophosphate }\end{array}$ \\
\hline $\mathrm{HCl}-\mathrm{P}$ & & $\mathrm{P}$ fixated in $\mathrm{Ca}$ and $\mathrm{Mg}$ minerals (carbonates and apatite); relatively stable under alkaline conditions \\
\hline Residual P & & Organic and refractory $\mathrm{P}$ of the Si cystal lattice \\
\hline
\end{tabular}

water interface (Mortimer et al., 1998). $D_{s}$ is the effective diffusion coefficient; and $D_{0}$ is the molar diffusion coefficient of the sediment, which is dependent on porosity and temperature (Chowdhury and Bakri, 2006). The parameter $D_{s}$ is approximately related to $D_{0}$ by the relation (Ullman and Aller, 1982; Ullman and Sandstrom, 1987):

$D_{s}=\phi D_{0} \phi \leq 0.7$

$D_{s}=\phi^{2} D_{0} \phi \geq 0.7$

The porosity $(\phi)$ of sediments at each sampling site was assumed to be more than 0.7 and the corresponding $D_{s}=\phi^{2} D_{0}$. The water temperature of the hypolimnion had little differrence and the average value was $18{ }^{\circ} \mathrm{C}$, so calculated $D_{0}$ $\left(\mathrm{H}_{2} \mathrm{PO}_{4}^{-}\right)=7.15 \times 10^{-6} \mathrm{~cm}^{2} \mathrm{~s}^{-1}$ (Krom and Berner, 1980).

\section{Results and Discussion}

\section{1. pH}

The $\mathrm{pH}$ values of vertical profiles decreased with depth across sediment-water interface and sediment $\mathrm{pH}$ values were lower than that of respective overlying water (Figure 2). The cause of this phenomenon maybe the gradual enhance of organic evolution and degradation with increasing depth (Xiao et al., 2011). The $\mathrm{pH}$ values at sediment-water interface were medium weak alkaline and ranged from 6.4 to 8.2 except for the sediment $\mathrm{pH}$ values of MDX03 and XX03, which were lower than 7.0. The vertical changes between CJBD and CTH were not significant, mainly correlated with the relatively similar environment conditions. Previous studies indicate that the $\mathrm{pH}$ value of the overlying water and sediment was a dominating factor (Ramin and Bates, 1979), while $\mathrm{P}$ release from the sediments occurred in neutral condition was less favorable than in both acidic and alkaline conditions (Jin et al., 2006b). So the currently pH values of sediments in the TGR would not significantly promote the $\mathrm{P}$ release.

\subsection{Pi Concentrations of Water Body}

Pi concentrations of water samples at different sites in the TGR varied greatly (Figure 3 ). For each sampling site, the average Pi concentration of open water was expressed as the average values of the surface, middle and bottom water of the vertical profiles. The result shows that average Pi concentration of water body was in the order of surface pore water $(0.052 \mathrm{mg} / \mathrm{L})>$ overlying water $(0.035 \mathrm{mg} / \mathrm{L})>$ open water $(0.018 \mathrm{mg} / \mathrm{L})$. The export of $\mathrm{P}$ from surface sediments may act as a $\mathrm{P}$ source in the TGR. Because the sediment contains large quantities of dissolved substances, and the pore water as the medium of dissolved substances in the transportation from sediment to overlying water (Wu et al., 1996), has relatively higher Pi concentration than the corresponding overlying water and open water.

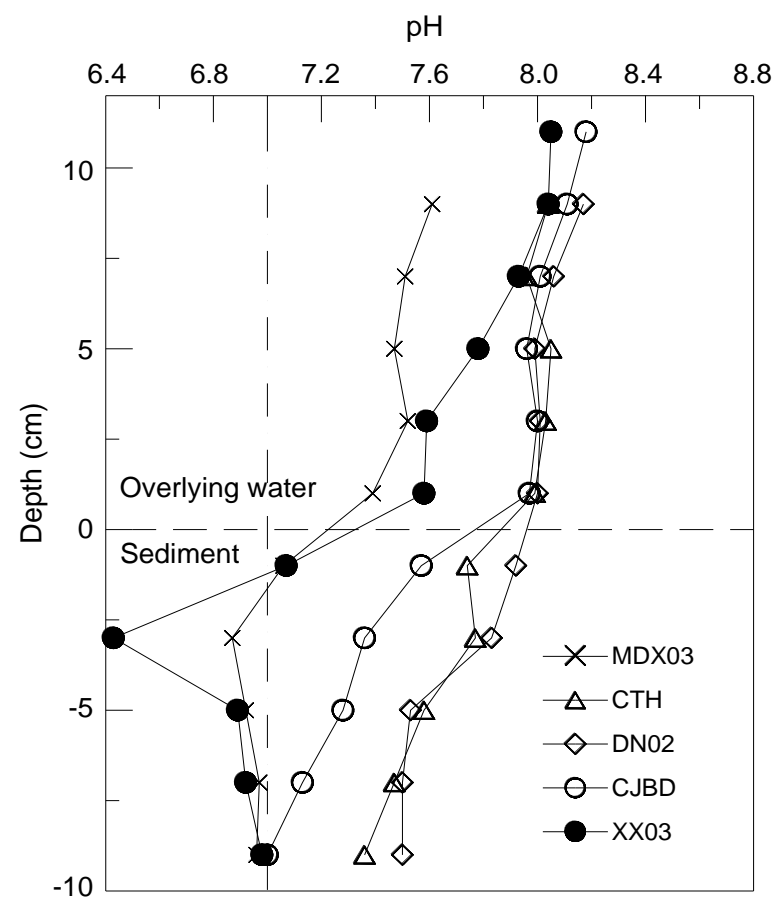

Figure 2. Vertical distributions of $\mathrm{pH}$ values at the sedimentwater interface of different sampling locations.

The maximum and minimum of Pi concentrations occurred at MDX03 and DN02, which were appropriate for the three kinds of water body. There are several small hydropower stations in the Modaoxi River (Sun et al., 2011), such as Fotang, Ganchang and Changtan power station, probably due to the dam foundation, the deposition of external and internal organic matters resulted in the accumulation of phosphorous in the reservoir sediment (Liu et al., 2009) and then Modaoxi River had the highest Pi concentration among the sampling 
sites. In contrast, Daning River appeared a better ecology and environment, owing to its relatively less population and high vegetation coverage ( $\mathrm{Ji}$ et al., 2010; Yang et al., 2010). In the whole profile, Pi concentrations exhibited a steep increase at the surface sediment of MDX03, CTH and XX03, this and phenomenon was pervasively observed both in laboratory experiments (Bartoli et al., 2009; Jensen et al., 1995; Moore et al., 1998) and in field (Clavero et al., 2000; Jensen and Thamdrup, 1993; Kleeberg et al., 2010; Søndergaard, 2007; Selig and Schlungbaum, 2003). The Xiangxi River had a high and relatively fluctuant $\mathrm{Pi}$ concentration distribution across the sediment-water interface (Figure 4). Two reasons may be responsible to it. One is the high soil background value of phosphorrus in the Xiangxi River basin, which was mainly caused by the drainages of phosphorus diggings and factory discharges ( $\mathrm{Li}$ et al., 2007b), the other reason is the occurrence of the density currents in distributaries bay, and the latter is probably the main cause. Density currents are mainly resulted from the water temperature differrence between the mainstream of the Yangtze River and tributaries bay (Ji et al., 2010; Yang et al., 2010). The upstream water of distributaries mainly flow down the slope and out of the bay driven by a bottom density current, meanwhile, the mainstream water of the Yangtze River enters into these backwater bays in reverse density currents. Thus Pi concentrations of the open water or at the sedimentwater interface in the distributaries bay were fluctuated, which was influenced by continuous and complex water exchanging between these backwater bays and the mainstream of the Yangtze River.

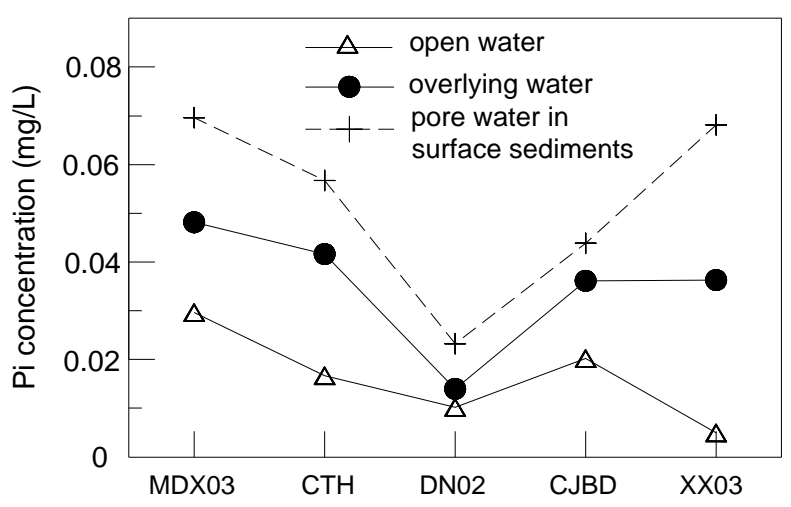

Figure 3. The average Pi concentrations of the open water, overlying water, and pore water $(0 \sim 4 \mathrm{~cm})$.

\subsection{TP Contents and Phosphorus Fractions Composition}

The amounts of TP in surface sediments $(0 \sim 2 \mathrm{~cm})$ of the five sampling sites with the mean value of $636.4 \mathrm{mg} / \mathrm{kg}$, ranged at $415.5 \sim 1,047.9 \mathrm{mg} / \mathrm{kg}$, which is similar to Han River, Korea (580 1,450 mg/kg) (Kim et al., 2004), and lower than that of Haihe River, China (968 2,017 mg/kg) (Sun et al., 2009). The sediment TP contents of five sampling sites were in the order of XX03 $(1,047.9 \mathrm{mg} / \mathrm{kg})>\mathrm{CJBD}(666.2$ $\mathrm{mg} / \mathrm{kg})>\mathrm{CTH}(624.1 \mathrm{mg} / \mathrm{kg})>\mathrm{DN} 02(428.5 \mathrm{mg} / \mathrm{kg})$. It im- plies that the P load in the TGR sediments was not significant and Xiangxi River has relatively higher P load. The contents of different $\mathrm{P}$ fractions in surface sediments ranged greatly (Figure 5). For all sampling sites, surface $\mathrm{P}$-fractions was in the order: $\mathrm{HCl}-\mathrm{P}>\mathrm{Res}-\mathrm{P}>\mathrm{NaOH}-\mathrm{P}>\mathrm{BD}-\mathrm{P}>\mathrm{NH}_{4} \mathrm{Cl}-$ $\mathrm{P}$, except XX03 with sequence of HCl-P > BD-P > Res-P > $\mathrm{NaOH}-\mathrm{P}>\mathrm{NH}_{4} \mathrm{Cl}-\mathrm{P}$. The predominant fraction was $\mathrm{HCl}-\mathrm{P}$, and this distribution pattern was in accordance with that of the previous studies (Wang et al., 2008).

The $\mathrm{HCl}-\mathrm{P}$ represents the $\mathrm{P}$ fraction sensitive to low $\mathrm{pH}$ and is fixated in $\mathrm{Ca}$ and $\mathrm{Mg}$ minerals (carbonates and apatite) (Christophoridis and Fytianos, 2006). HCl-P is a relatively stable fraction of sedimentary $\mathrm{P}$ and contributes to a permanent burial of $P$ in the sediments (Hupfer et al., 1995). The HCl-P contents in surface sediments varied from 164.5 to $687.2 \mathrm{mg} / \mathrm{kg}$, and the relative contribution ranged at $38.4 \sim$ $65.6 \%$. Xiangxi River had the highest HCl-P contents and percentage among the sampling sites. Previous studies reported that the relatively higher $\mathrm{HCl}-\mathrm{P}$ content can be attributed to the calcareous terrain of the recharge area (Jin et al., 2006b; Sun et al., 2009).

The $\mathrm{NH}_{4} \mathrm{Cl}-\mathrm{P}$ represents the loosely sorbed $\mathrm{P}$ in the sediments and is readily soluble under all conditions (Christophoridis and Fytianos, 2006). In the sampling sites of the TGR, the mean $\mathrm{NH}_{4} \mathrm{Cl}-\mathrm{P}$ amounts in surface sediments were the lowest among the five $\mathrm{P}$ fractions. The highest $\mathrm{NH}_{4} \mathrm{Cl}-\mathrm{P}$ amount was observed in XX03 (15.9 mg/kg), which was almost three times than that in MDX03 $(5.9 \mathrm{mg} / \mathrm{kg})$. The percentage of $\mathrm{NH}_{4} \mathrm{Cl}-\mathrm{P}$ contributing to $\mathrm{TP}$ was in the range of $1.4 \sim 2.2 \%$. These results indicated that the $\mathrm{NH}_{4} \mathrm{Cl}-\mathrm{P}$ contributed little to TP in surface sediments.

The BD-P represents the redox-sensitive $\mathrm{P}$ forms, mainly bound to the surface of Fe (III) and Mn oxides and hydroxides (Christophoridis and Fytianos, 2006). This fraction is considered as potentially mobile pool of P (Kaiserli et al., 2002; Rydin, 2000), released by reductive Fe dissolution from anaerobic sediments (Christophoridis and Fytianos, 2006) and acted as an internal P source to the overlying water (Kleeberg and Kozerski, 1998). The BD-P amounts in the surface sediments ranged from $34.0 \mathrm{mg} / \mathrm{kg}$ (DN02) to $104.8 \mathrm{mg} / \mathrm{kg}$ (XX03), which contributed $7.9 \sim 11.2 \%$ to the TP and the percentage in different sites showed little difference. DO depletion, high $\mathrm{pH}$ level or bacterial activity that might enhance P-release from BD-P fraction, while high organic content in sediments might inhibit binding of $\mathrm{P}$ by $\mathrm{Fe}$, by competition from binding sites (Kleeberg and Kozerski, 1998).

$\mathrm{NaOH}-\mathrm{P}$ is the $\mathrm{P}$ fraction sorbed on the surface of aluminum hydroxides and the interior of ferric oxides of the sediment particles (Christophoridis and Fytianos, 2006), which is stored relatively as stable forms (Zhang et al., 2011). A 10.1 $\sim 18.8 \%$ sedimentary TP in the studied samples was $\mathrm{NaOH}-\mathrm{P}$, which ranged from 75.8 to $111.5 \mathrm{mg} / \mathrm{kg}$ (Figure 5). Residual P consists mainly of refractory organic $\mathrm{P}$ as well as the inert inorganic P fraction (Rydin, 2000), ranged from 96.0 (CTH) to $140.8 \mathrm{mg} / \mathrm{kg}$ (DN02) at the five sites. The percentages of 
$\mathrm{Pi}$ concentration $(\mathrm{mg} / \mathrm{L})$

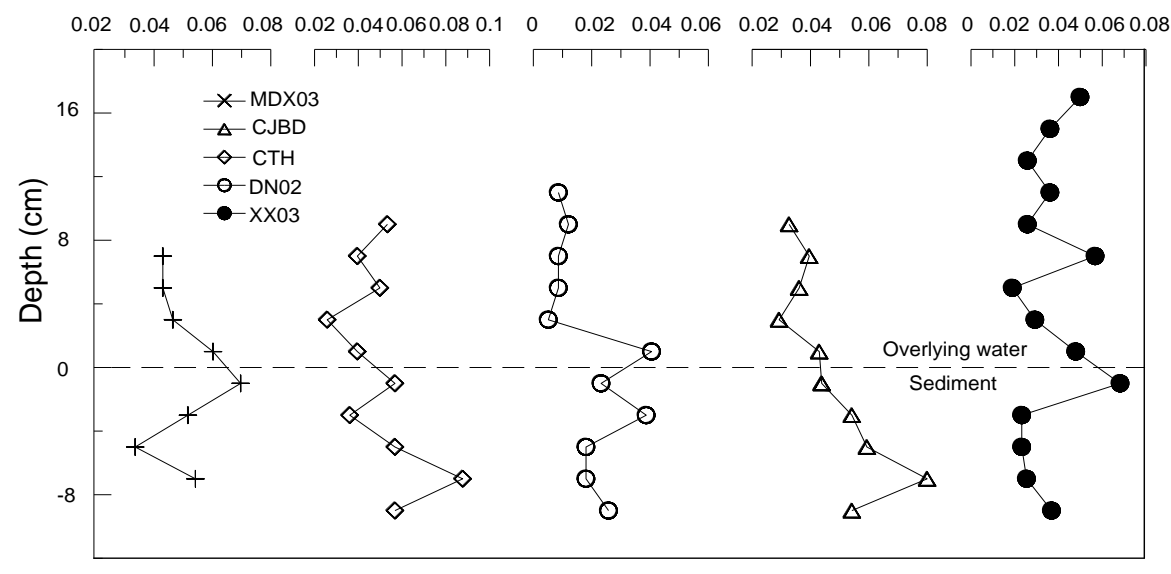

Figure 4. Pi concentrations of pore water and the correspondding overlying water.

Res-P in DN02 and MDX03 were even above 25\%. This $\mathrm{P}$ fraction is considered to be "permanently bound" in comparison with other extract P forms (Rydin, 2000).

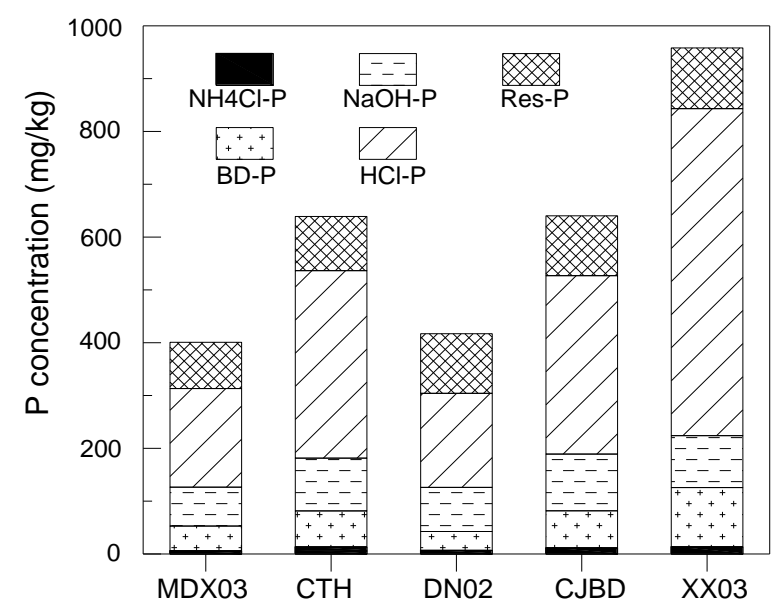

Figure 5. Concentrations of different $P$ forms in surface sediments $(0-2 \mathrm{~cm})$ at the five sampling sites in the TGR.

Profile concentrations of various $\mathrm{P}$ forms in the sediments from five sampling sites are shown in Figure 6. The concentrations of $\mathrm{NH}_{4} \mathrm{Cl}-\mathrm{P}$ and BD-P, acted as mobile P (Gächter et al., 1992), ranged from 35.6 to $157.4 \mathrm{mg} / \mathrm{kg}$ and contributed $8.4 \sim 15.8 \%$ to the TP. Both $\mathrm{NH}_{4} \mathrm{Cl}-\mathrm{P}$ and BD-P were stable throughout the sediment profile (except for XX03). XX03 had higher mean concentration $(125.7 \mathrm{mg} / \mathrm{kg})$ and mean percentage $(13.2 \%)$ of mobile $\mathrm{P}$ than other sampling sites, which was consistent with the results that Xiangxi River has relatively higher $\mathrm{P}$ load ( $\mathrm{Li}$ et al., 2007b). The contents of HCl-P declined at $0 \sim 4 \mathrm{~cm}$ depth, over this depth interval there was an increase in the sampling sites. The increase of $\mathrm{HCl}-\mathrm{P}$ in the sediment profile could have been due to the formation of refractory inorganic P forms during "aging" of the sediment (Rydin, 2000), where occlusion of P was one possibility (Froelich, 1988). In different sites the concentrations of $\mathrm{NaOH}-\mathrm{P}$ and Res-P varied greatly in the sediment profiles. The sampling sites of CJBD, DN02 and MDX03 in the whole profile followed the same order as surface sediments, which was HCl-P > Res-P > NaOH-P > BD-P > $\mathrm{NH}_{4} \mathrm{Cl}-\mathrm{P}$. At site $\mathrm{CTH}$, the rank order was $\mathrm{HCl}-\mathrm{P}>\mathrm{NaOH}-\mathrm{P}$, Res-P > BD-P > $\mathrm{NH}_{4} \mathrm{Cl}-\mathrm{P}$. And the rank order was $\mathrm{HCl}-\mathrm{P}>$ BD-P, Res-P, NaOH-P > $\mathrm{NH}_{4} \mathrm{Cl}-\mathrm{P}$ at $\mathrm{XX03}$. The trend of profile concentrations of various $\mathrm{P}$ forms between $\mathrm{CTH}$ and CJBD was similar, which reveals that the sampling site of $\mathrm{CTH}$, located in estuary, was intensely influenced by the main stream.

\subsection{Estimated Pi Release Fluxes}

Release fluxes of orthophosphate $(\mathrm{Pi})$ between water and sediments were summarized in Table 3 , which ranged from $-0.003 \mathrm{mg} / \mathrm{m}^{2} / \mathrm{d}(\mathrm{XX03})$ to $0.013 \mathrm{mg} / \mathrm{m}^{2} / \mathrm{d}$ (MDX03) at the five sites. Negative values indicates Pi flux from water column into sediment (Moore et al., 1998). The result shows that the sediment in Xiangxi River might be a sink for phosphorus (negative flux), while the sediments at other sampling sites acted as P sources (positive fluxes) (Ullman and Sandstrom, 1987). The reasons might lie that the sediments in the TGR were newly and quickly deposited (Liu et al., 2012) and high Pi content of runoff (Luo et al., 2007) might reduce the P releasing rate from the sediments.

Compared with other studies, the Pi fluxes of the five sampling sediments in the TGR was relatively lower than that of Lake Dudinghausen (Chowdhury and Bakri, 2006) and Suma Park Reservoir (Chowdhury and Bakri, 2006). The minimum Pi flux for Xiangxi River (XX03) was even -0.003 $\mathrm{mg} / \mathrm{m}^{2} / \mathrm{d}$. Due to the sample was obtained in flood period, high $\mathrm{Pi}$ content of runoff and environmental conditions prompted XX03 as a sink of P. However, there are several factors influencing the P-release on the sediment-water interface, such as advection, bioturbation, irrigation, physical wave activity and current effects (Selig and Schlungbaum, 


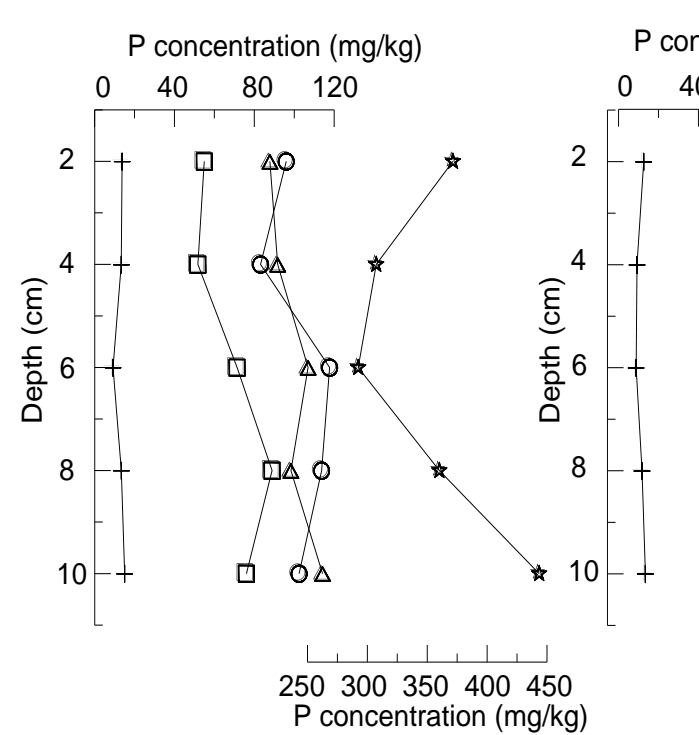

(a)

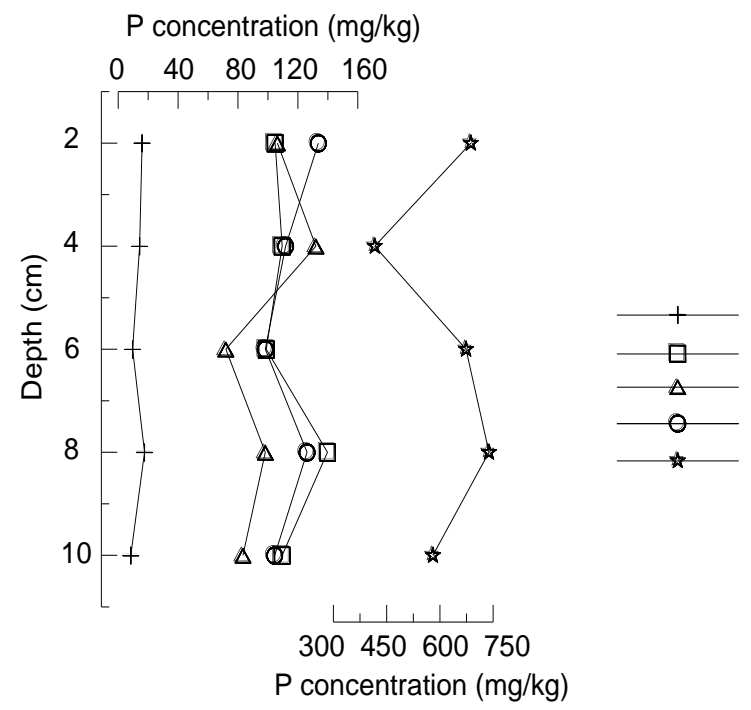

(d) concentration $(\mathrm{mg} / \mathrm{kg}) \quad \mathrm{P}$ concentration $(\mathrm{mg} / \mathrm{kg})$

$0 \quad 40 \quad 80120 \quad 160$

$80 \quad 120$
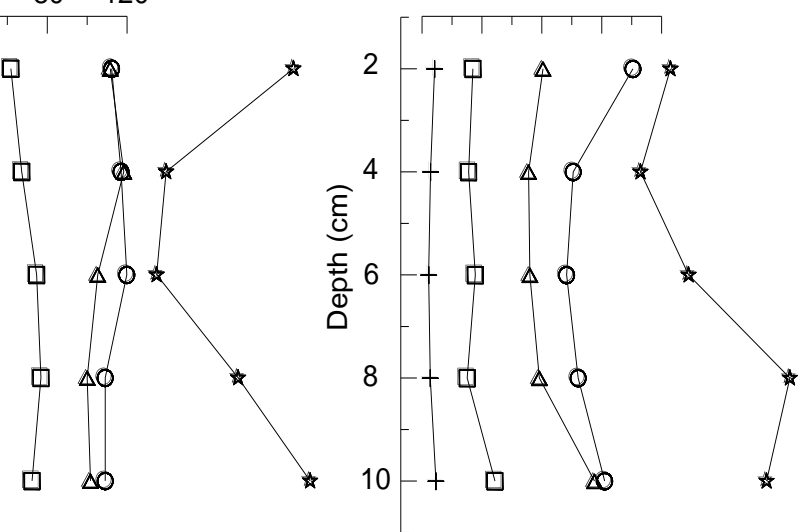

270300330360390

$\mathrm{P}$ concentration $(\mathrm{mg} / \mathrm{kg})$

(b)

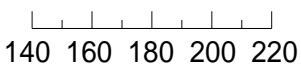

$\mathrm{P}$ concentration $(\mathrm{mg} / \mathrm{kg})$

(c)

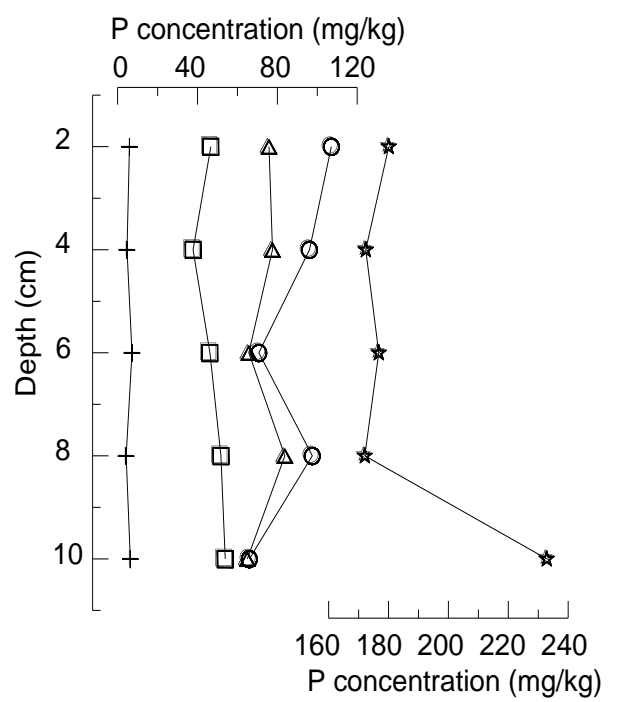

(e)

Figure 6. $\mathrm{P}$ forms in the sediment profiles from five sampling sites of the TGR, (a) at CTH; (b) at CJBD; (c) at DN02; (d) at XX03; (e) at MDX03.

Table 3. Comparison of $P_{i}$ Fluxes among the Five Sampling Sites and Other Areas

\begin{tabular}{lll}
\hline Site & $\mathrm{P}_{\mathrm{i}}$ fluxes $\left(\mathrm{mg} / \mathrm{m}^{2} / \mathrm{d}\right)$ & Reference \\
\hline Three Gorges Reservoir, China & $-0.003-0.013$ & This study \\
Lake Dudinghausen, Germany & $0.041-0.567$ & Selig and Schlungbaum, 2003 \\
Lake Tiefer, Germany & $0.060-0.151$ & Selig and Schlungbaum, 2003 \\
Suma Park Reservoir, Australia & $0.05-0.22$ & Chowdhury and Bakri, 2006 \\
Chaffey Reservoir, Australia & $0.03-0.91$ & Sherman et al., 2001 \\
\hline
\end{tabular}

2003). In addition, Pi flux from sediments is very sensitive to changes in $\mathrm{O}_{2}$ status of the overlying water, with anaerobic conditions promoting large P fluxes (Moore et al., 1998). In conclusion, the sediments of the TGR acted both as a source and a sink for phosphorus, with relatively low Pi fluxes across the sediment-water interface in summer. But due to the slower water flow, TP concentrations were decreased according to particulate deposition. However, the $\mathrm{P}$ load in sediments would release back to water under specific conditions (Yang et al., 2010). The density current was the main form of the 
water exchange between mainstream and tributaries of the TGR (Yang et al., 2010), and the main stream reverse effect could aggravate the eutrophication of TGR water (Luo et al., 2007). The plunging depth and length of the density current were varied with seasonal variation of physico-chemical properties of water, the upstream inflow, water level in TGR and water level daily fluctuations (Ji et al., 2010), which might be an important determinant of mixing depth in Xiangxi River (Liu et al., 2012). In addition, TP concentration of surface water in the main stream of the Yangtze River was higher than tributaries bay (Yang et al., 2010). The main form of $\mathrm{P}$ was dissolved phosphorus in Spring (May) and Winter (February) while particle phosphorus was the main forms of $\mathrm{P}$ in summer (August) (Zeng et al., 2012). So, the values and changing features of Pi fluxes in other seasons of the TGR should be taken further research.

\section{Conclusions}

This study evaluated sediment characteristics, $\mathrm{P}$ forms and orthophosphate $(\mathrm{Pi})$ concentrations as well as Pi release fluxes across the sediment-water interface in five sampling sites of the Three Gorges Reservoir (TGR). The TP contents of surface sediments $(0 \sim 2 \mathrm{~cm})$ ranged from 415.5 to $1,047.9$ $\mathrm{mg} / \mathrm{kg}$, with the mean value of $636.4 \mathrm{mg} / \mathrm{kg}$, where the mean values of $\mathrm{NH}_{4} \mathrm{Cl}-\mathrm{P}, \mathrm{BD}-\mathrm{P}, \mathrm{NaOH}-\mathrm{P}, \mathrm{HCl}-\mathrm{P}$, and Res-P contents were $11.3,60.4,92.4,354.3$ and $118.0 \mathrm{mg} / \mathrm{kg}$, respectively. The main rank order of P-fractions was: HCl-P > Res-P > $\mathrm{NaOH}-\mathrm{P}>\mathrm{BD}-\mathrm{P}>\mathrm{NH}_{4} \mathrm{Cl}-\mathrm{P}$, and the predominant fraction was $\mathrm{HCl}-\mathrm{P}$, which is a relatively stable fraction of sedimentary $\mathrm{P}$. TP contents and main $\mathrm{P}$ fraction $(\mathrm{HCl}-\mathrm{P})$ indicates that the $\mathrm{P}$ load in the TGR sediments was not significant.

Sediment $\mathrm{pH}$ values decreased with depth at all sites and was lower than that of respective overlying water. The average $\mathrm{Pi}$ concentration of water body was in the order of surface pore water $(0.018 \mathrm{mg} / \mathrm{L})>$ overlying water $(0.035 \mathrm{mg}$ $/ \mathrm{L})>$ open water $(0.052 \mathrm{mg} / \mathrm{L})$, which indicated that the export of $\mathrm{P}$ from surface sediments might act as a $\mathrm{P}$ source in the TGR. The release fluxes of orthophosphate (Pi) across sediment-water interface ranged from $-0.003 \mathrm{mg} / \mathrm{m}^{2} / \mathrm{d}(\mathrm{XX}-03)$ to $0.013 \mathrm{mg} / \mathrm{m}^{2} / \mathrm{d}$ (MDX03) at the five sites. In summer, the sediment of Xiangxi River might be a sink for phosphorus, while the sediments of other sampling sites acted as P sources.

Acknowledgments. This work was funded by National Science Foundation of China (No. 41273110, No.51179205) and Major Science and Technology Program for Water Pollution Control and Treatment (Grand No. 2012ZX07104-001). We thank G. C. Wu, L. Liu, F. Peng, X. J. Zhang and R. Li for their help in the field sampling and experiment. We also acknowledge the assistance from the colleagues of State Key Laboratory of Loess and Quaternary Geology, Institute of Earth Environment and Chinese Academy of Sciences.

\section{References}

Abrams, M.M., and Jarrell, W.M. (1995). Soil phosphorus as a potential nonpoint source for elevated stream phosphorus levels. $J$.
Environ. Qual., 24(1), 132-138. http://dx.doi.org/10.2134/jeq199 $5.00472425002400010019 \mathrm{x}$

Andersen, J.M. (1974). Nitrogen and phosphorus budgets and the role of sediments in six shallow Danish lakes. Arch. Hydrobiol., 74(4), 528-550.

Bakri, D.A., and Chowdhury, M. (2006). Internal nutrient flux in an inland water supply reservoir, New South Wales, Australia. Lakes Reserv.: Res. Manage., 11(1), 39-45. http://dx.doi.org/10.1111/j.14 40-1770.2006.00286.x.

Bartoli, M., Longhi, D., Nizzoli, D., Como, S., Magni, P., and Viaroli, P. (2009). Short term effects of hypoxia and bioturbation on solute fluxes, denitrification and buffering capacity in a shallow dystrophic pond. J. Exp. Mar. Biol. Ecol., 381(2), 105-113. http://dx.doi. org/10.1016/j.jembe.2009.09.018.

Berner, R.A. (1980). Early diagenesis: A theoretical approach. Princeton University Press.

Boström, B. (1988). Relations between chemistry, microbial biomass and activity in sediments of a sewage-polluted vs. a nonpolluted eutrophic lake. Internationale Vereinigung fuer Theoretische und Angewandte Limnologie Verhandlungen IVTLAP, 23(1), 451-459.

Chen, K.F., Yang, D.Y., Jiang, H.T., Zhou, B., Xu, Y.H., Liu, Q.Y., and Dong, J. (2004). The geochemistry characteristic of weeathering crust in the Three Gorge Areas-The example of CaoTang River drainage area in the Three Gorge Areas. J. East China Inst. Technol., 27(2), 141-146.

Chowdhury, M., and Bakri, D.A. (2006). Diffusive nutrient flux at the sediment-water interface in Suma Park Reservoir, Australia. Hydrol. Sci. J., 51(1), 144-156. http://dx.doi.org/10.1623/hysj.51.1. 144.

Christophoridis, C., and Fytianos, K. (2006). Conditions affecting the release of phosphorus from surface lake sediments. J. Environ. Qual., 35(4), 1181-1192. http://dx.doi.org/10.2134/jeq2005.0213.

Clavero, V., Izquierdo, J.J., Fernandez, J.A., and Niell, F.X. (2000). Seasonal fluxes of phosphate and ammonium across the sediment-water interface in a shallow small estuary (Palmones River, southern Spain). Mar. Ecol. Prog. Ser., 198, 51-60.

Correll, D.L. (1998). The role of phosphorus in the eutrophication of receiving waters: A review. J. Environ. Qual., 27(2), 261-266. http: //dx.doi.org/10.2134/jeq1998.00472425002700020004x

Dahl, M., Dunning, C.P., and Green, T. (1993). Convective transport of chemicals across a sediment-water interface. Water Sci. Technol., 28(8-9), 209-213.

Deng, C.G., and Gong, L. (2007). The Study on the Trend of Eutrophication in the Three Gorges Reservoir. J. Agro-Environ. Sci., 26, 279-282. doi:10.3321/j.issn:1672-2043.2007.z1.064.

Egemose, S., Wauer, G., and Kleeberg, A. (2009). Resuspension behaviour of aluminium treated lake sediments: effects of ageing and pH. Hydrobiologia, 636(1), 203-217. http://dx.doi.org/10.1007/s10 750-009-9949-8.

Froelich, P.N. (1988). Kinetic control of dissolved phosphate in natural rivers and estuaries: A primer on the phosphate buffer mechanism. Limnol. Oceanogr, 33(4), 649-668.

Fu, B.J., Wu, B.F., Lü, Y.H., Xu, Z.H., Cao, J.H., Niu, D., Yang, G.S., and Zhou, Y.M. (2010). Three Gorges Project: Efforts and challenges for the environment. Prog. Phys. Geog., 34(6), 741-754. http:// dx.doi.org/10.1177/0309133310370286.

Gächter, R., Tessier, A., Szabo, E., and Carignan, R. (1992). Measurement of total dissolved phosphorus in small volumes of iron rich interstitial water. Aquat. Sci., 54(1), 1-9. http://dx.doi.org/10. 1007/BF00877261.

Hua, L.Z., He, X.B., Yan, C.Z., Wei, J., and Nan, H.W. (2009). Assessment of sediment delivery Ratio in Daning River Watershed based on AnnAGNPS Model. Bull. Soil Water Conserv., 29(3), 154 $-158$. 
Huang, Z.L. (2001). Biodiversity conservation for the Three Gorges project. Chin. Biodivers., 9(4), 472-481. http://dx.doi.org/10.3321/j. issn:1005-0094.2001.04.021.

Hupfer, M., Gächter, R.. and Giovanoli, R. (1995). Transformation of phosphorus species in settling seston and during early sediment diagenesis. Aquat. Sci., 57(4), 305-324. http://dx.doi.org/10.1007/ BF00878395.

Jensen, H.S., and Andersen, F.Ø. (1992). Importance of temperature, nitrate, and $\mathrm{pH}$ for phosphate release from aerobic sediments of four shallow, eutrophic lakes. Limnol. Oceanogr., 37(3), 577-589.

Jensen, H.S., Mortensen, P.B., Andersen, F.Ø., Rasmussen, E., and Jensen, A. (1995). Phosphorus cycling in a coastal marine sediment, Aarhusbay, Denmark. . Limnol. Oceanogr., 40(5), 908-917.

Jensen, H.S., and Thamdrup, B. (1993). Iron-bound phosphorus in marine sediments as measured by bicarbonate-dithionite extraction. Hydrobiologia, 253(1-3), 47-59. http://dx.doi.org/10.1007/bf0005 0721.

Ji, D.B., Liu, D.F., Yang, Z.J., and Xiao, S.B. (2010). Hydrodynamic characteristics of Xiangxi Bay in Three Gorges Reservoir. Sci. Sin. Phys., Mech. Astron., 40(1), 101-112.

Jin, X.C., Wang, S.R., Bu, Q.Y., and Wu, F.C. (2006a). Laboratory experiments on phosphorous release from the sediments of 9 lakes in the middle and lower reaches of Yangtze River region, China. Water Air Soil Pollut, 176(1-4), 233-251. http://dx.doi.org/10.1007 /s11270-006-9165-3.

Jin, X.C., Wang, S.R., Pang, Y., and Wu, F.C. (2006b). Phosphorus fractions and the effect of $\mathrm{pH}$ on the phosphorus release of the sediments from different trophic areas in Taihu Lake, China. Environ. Pollut., 139(2), 288-295. http://dx.doi.org/10.1016/j.env pol.2005.05.010.

Kaiserli, A., Voutsa, D., and Samara, C. (2002). Phosphorus fractionation in lake sediments-Lakes Volvi and Koronia, N. Greece. Chemosphere, 46(8), 1147-1155. http://dx.doi.org/10.1016/S00456535(01)00242-9.

Khan, F.A., and Ansari, A.A. (2005). Eutrophication: an ecological vision. Bot. Rev., 71(4), 449-482. http://dx.doi.org/10.1663/00068101(2005)071[0449:EAEV]2.0.CO;2.

Kim, L.H., Choi, E., Gil, K.I., and Stenstrom, M.K. (2004). Phosphorus release rates from sediments and pollutant charac- teristics in Han River, Seoul, Korea. Sci. Total. Environ., 321(1-3), 115-125. http://dx.doi.org/10.1016/j.scitotenv.2003.08.018.

Kim, L.H., Choi, E., and Stenstrom, M.K. (2003). Sediment characteristics, phosphorus types and phosphorus release rates between river and lake sediments. Chemosphere, 50(1), 53-61. http://dx.doi. org/10.1016/S0045-6535(02)00310-7.

Kleeberg, A., Herzog, C., Jordan, S., and Hupfer, M. (2010). What drives the evolution of the sedimentary phosphorus cycle? Limnologica, 40(2), 102-113. http://dx.doi.org/10.1016/j.limno.2009.11. 001.

Kleeberg, A., and Kozerski, H.P. (1998). Phosphorus release in Lake Großer Müggelsee and its implications for lake restoration. Hydrobiologia, 342/343, 9-26. http://dx.doi.org/10.1023/A:1017079029 053.

Krom, M.D., and Berner, R.A. (1980). The diffusion coefficients of sulfate, ammonium, and phosphate ions in anoxic marine sediments. Limnol. Oceanogr., 25(2), 327-337.

Li, C.M., Huang, Z.L., Zhang, S., and Chang, J.B. (2007a). Risk forecast of algal bloom in the Three Gorges Reservoir. Resour. Environ. Yangtze Basin, 16(1), 1-6.

Li, F.Q., Ye, L., Liu, R.Q., Cao, M., and Cai, Q.H. (2007b). Investigation on aquatic environmental factors in Xiangxi River watershed. Ecol. Sci., 26(3), 199-207.

Li, F.Q., Ye, L., Liu, R.Q., Cao, M., and Cai, Q.H. (2008). Dynamics of main nutrient input to Xiangxi Bay of the Three-Gorges Reservoir. Acta Ecol. Sin., 28(5), 2073-2079. http://dx.doi.org/10.1016/ S1872-2032(08)60044-X.

Liu, C., Wang, Q.X., and Watanabe, M. (2006). Nitrogen transported to three Gorges Dam from agro-ecosystems during 1980-2000. Biogeochemistry, 81(3), 291-312. http://dx.doi.org/10.1007/s10533 -006-9042-6.

Liu, C.Q., Wang, F.S., Wang, Y.C., and Wang, B.L. (2009). Responses of aquatic environment to river daming-from the geochemical view. Resour. Environ. Yangtze Basin, 18(4), 384-396.

Liu, L., Liu, D.F., Johnson, D.M., Yi, Z.Q., and Huang, Y.L. (2012). Effects of vertical mixing on phytoplankton blooms in Xiangxi Bay of Three Gorges Reservoir: Implications for management. Water Res., 46, 2121-2130. http://dx.doi.org/10.1016/j.watres.2012. 01.029 .

Luo, Z.X., Zhu, B., Zheng, B.H., and Zhang, Y. (2007). Nitrogen and phosphorus loadings in branch backwater reaches and the reverse effects in the main stream in Three Gorges Reservoir. China Environ. Sci., 27(2), 208-212.

Moore, P.A., Reddy, K.R., and Fisher, M.M. (1998). Phosphorus flux between sediment and overlying water in Lake Okeechobee, Florida: spatial and temporal variations. J. Environ. Qual., 27(6), 14281439.http://dx.doi.org/10.2134/jeq1998.00472425002700060020x

Mortimer, R.J.G., Krom, M.D., Watson, P.G., Frickers, P.E., Davey, J.T., and Clifton, R.J. (1998). Sediment-water exchange of nutrients in the intertidal zone of the Humber Estuary, UK. Mar. Pollut. Bull., 37(3-7), 261-279. http://dx.doi.org/10.1016/S0025326X(99)00053-3.

Murphy, J., and Riley, J.P. (1962). A modified single solution method for the determination of phosphate in natural waters. Anal. Chim. Acta., 27, 31-36. http://dx.doi.org/10.1016/S0003-2670(00)884445.

Ramin, N., and Bates, M.H. (1979). The effects of $\mathrm{pH}$ on the aluminum, iron and calcium phosphate fractions of lake sediments. Water Res., 13, 813-815. http://dx.doi.org/10.1016/0043-1354(79) 90247-1.

Rydin, E. (2000). Potentially mobile phosphorus in Lake Erken sediment. Water Res., 34(7), 2037-2042. http://dx.doi.org/10.1016/ S0043-1354(99)00375-9.

Søndergaard, M. (2007). Nutrient dynamics in lakes-with emphasis on phosphorus, sediment and lake restoration. Ph.D. dissertation, Freshwater Ecology, University of Aarhus, Denmark.

Selig, U., and Schlungbaum, G. (2003). Characterisation and quantification of phosphorus release from profundal bottom sediments in two dimictic lakes during summer stratification. J. Limnol., 62 (2), 151-162.

Sherman, B., Ford, P., Hatton, P., Whittington, J., Green, D., Baldwin, D., Oliver, R., Shiel, R., Berkel, J.v., Beckett, R., Grey, L., and Maher, B. (2001). The Chaffey Dam Story. Final report for CRCFE projects B.202 and B.203. Murray-Darling Freshwater Research Centre.

Sun, R., Yuan, X.Z., Liu, H., and Li, X. (2011). Influence of cascaded exploitation of small hydropower on riparian plant communities in Modaoxi River. Adv. Water Sci., 22(4), 561-567. http://dx.doi.org/ CNKI: $32 \cdot 1309 \cdot P \cdot 20110514 \cdot 1449 \cdot 019$.

Sun, S.J., Huang, S.L., Sun, X.M., and Wen, W. (2009). Phosphorus fractions and its release in the sediments of Haihe River, China. $J$. Environ. Sci., 21(3), 291-295. http://dx.doi.org/10.1016/S10010742(08)62266-4.

Ullman, W.J., and Aller, R.C. (1982). Diffusion coefficients in nearshore marine sediments. Limnol. Oceanogr., 27(3), 552-556.

Ullman, W.J., and Sandstrom, M.W. (1987). Dissolved nutrient fluxes from the nearshore sediments of Bowling Green Bay, central Great Barrier Reef Lagoon (Australia). Estuar. Coast. Shelf Sci., 24, 289- 
303. http://dx.doi.org/10.1016/0272-7714(87)90051-5.

Wang, Y., Shen, Z.Y., Hu, L.J., and Niu, J.F. (2008). Adsorption and release of phosphorus from sediments from the main branches of the Three-Gorges Reservoir. Acta Sci. Circumstant., 28(8), 1654 -1661 .

Wang, Y.C., Huang, R.G., and Wan, G.J. (1998). A newly developed sampler for collecting samples near the lacustrine sediment-water interface. Geol. Geochem., 1(1), 94-96.

Wei, F.S., Qi, W.Q., and Hong, S.J. (2002). Water and wastewater monitoring and analysis method. 4th ed. Beijing: China Environmental Science Press.

Wu, F.C., Wan, G.J., and Cai, Y.R. (1996). Biogeochemical processes at the sediment-water interface. Adv. Earth Sci., 11(3), 191-197. http://dx.doi.org/10.3321/j.issn:1001-8166.1996.02.013

Wu, J.G., Huang, J.H., Han, X.G., Xie, Z.Q., and Gao, X.M. (2003). Three-Gorges Dam-Experiment in habitat fragmentation? Science, 300(5623), 1239-1240. http://dx.doi.org/10.1126/science.1083312.

Xiao, S.B., Liu, D.F., Wang, Y.C., Gao, B., Wang, L., and Duan, Y.J. (2011). Characteristics of heavy metal pollution in sediments at the Xiangxi Bay of Three Gorges Reservoir. Resour. Environ. Yangtze Basin, 20(8), 983-989.

Xie, L.Q., Xie, P., and Tang, H.J. (2003). Enhancement of dissolved phosphorus release from sediment to lake water by Microcystis blooms-an enclosure experiment in a hyper-eutrophic, subtropical Chinese lake. Environ. Pollut., 122, 391-399. http://dx.doi.org/10. 1016/S0269-7491(02)00305-6.

Yang, Z.J., Liu, D.F., Ji, D.B., and Xiao, S.B. (2010). Influence of the impounding process of the Three Gorges Reservoir up to water level $172.5 \mathrm{~m}$ on water eutrophication in the Xiangxi Bay. Sci. China Tech. Sci., 40(4), 1114-1125. http://dx.doi.org/10.1007/s114 31-009-0387-7.

Ye, L., Xu, Y.Y., Han, X.Q., and Cai, Q.H. (2006). Daily dynamics of nutrients and chlorophyll a during a Spring phytoplankton bloom in Xiangxi Bay of the Three Gorges Reservoir. J. Freshwater. Ecol., 21(2), 315-321. http://dx.doi.org/10.1080/02705060.2006.96 65001

Zeng, F.H., Zhang, S., Xiong, Q., Lv, P.L., and Lan, F. (2012). Seasonal variation of nitrogen and phosphorus in three-gorge reservoir. China Environ. Sci., 28(5), 29-32.

Zhang, S., Li, C.M., Zheng, B.H., Zhai, C.Z., Zheng, J., and Zhang, Q. (2007). Trophic states and nutrient output of tributaries bay in Three Gorges Reservoir after impoundment. Environ. Sci., 28(3), 500-505. http://dx.doi.org/10.3321/j.issn:0250-3301.2007.03.010

Zhang, Z.J., Wang, Z.D., Wang, Y.W., Chen, X.Y., Wang, H., Xu, X., Lin, X.Y., and Czapar, G.F. (2011). Properties of phosphorus retention in sediments under different hydrological regimes: A laboratory-scale simulation study. J. Hydrol., 404(3-4), 109-116. http:// dx.doi.org/10.1016/j.jhydrol.2010.06.018.

Zheng, B.H., Cao, C.J., Qin, Y.W., and Huang, M.S. (2008). Analysis of nitrogen distribution characters and their sources of the major input rivers of Three Gorges Reservoir. Environ. Sci., 29(1), 1-6. http://dx.doi.org/10.3321/j.issn:0250-3301.2008.01.001

Zhou, Q.X., Gibson, C.E., and Zhu, Y.M. (2001). Evaluation of phosphorus bioavailability in sediments of three contrasting lakes in China and the UK. Chemosphere, 42(2), 221-225. http://dx.doi. org/10.1016/S0045-6535(00)00129-6. 